\title{
Well Integrity Analysis and Application Based on FTA Method
}

\author{
Lili Yan ${ }^{1 *}$ \\ ${ }^{1}$ Production Research Institute, Shengli Oilfield, Sinopec Group Company, Dongying, China \\ *Lili Yan, E-mail: 11_job@163.com
}

Received: Novermber 28, 2016

doi: $10.22158 /$ rem.v2n1p20
Accepted: December 6, 2016 Online Published: December 9, 2016

URL: http://dx.doi.org/10.22158/rem.v2n1p20

\begin{abstract}
With the increase of development the well integcrity problem are becoming more and more serious. This article uses the Fault Tree Analysis (FTA) method for many factors, such as completion, production and operation process, pressure annulus, the cementing quality, the wellhead system and leakage of pipe string. Many wellbore risk factors to conduct a comprehensive analysis and evaluation. Through the qualitative analysis of wellbore integrity failure risk, determining the level of risk factors and establishing the damage analysis model of the wellbore. According to the selected blocks in Shengli Oilfield example analysis of single wells find out the minimum cut sets, the minimum path sets and structure importance. The results showed that the selected block probability of top event is calculated and it's 0.9961, and the actual selection conforms to statistics prove that the proposed based on the FTA wellbore damage risk analysis method is feasible, and through quantitative analysis and calculation of basic events of different important degree of parameters.

According to these risk factors for prevention of failure risk control measures are put forward, which provides reference for predict wellbore integrity to ensure the safety of oil and gas production run smoothly.
\end{abstract}

\section{Keywords}

well Integrity, FTA analysis, risk evaluation, preventive measures, application example

\section{Introduction}

Wellbore is the fluid passage inside the well and it is an important part of well control. Any point in the process of drilling and completion and production which fluid flow through maybe the place where fluid leak. It is always the most important problem in oil and gas field exploration and development to prevent the loss of control flow of formation fluid in oil and gas wells. Once the loss of control of formation fluid that especially the wellbore damage caused may lead to serious consequences. In the past years of oil field development, the number of fault wells increased year by year and the well integrity had been destroyed, which influenced the oil field development effect. 


\section{Risk Assessment Model Establishment of Wellbore Integrity}

\subsection{Principle of FTA Method}

Accident Tree Analysis (ATA) which originated from Fault Tree Analysis (FTA) is one of important analysis methods of safety system engineering, and it can identify and evaluate the risk of various systems. Accident tree analysis whose causality is intuitive, thinking is clear and logic is strong, can not only be used for qualitative analysis, but also quantitative analysis. This method which contains a set of analysis methods and evaluation process and combines qualitative and quantitative calculation model, reflects the systematicness, accuracy and predictability of safety system engineering in the research of safety problems. The original definition of the fault tree is as follows: from the beginning of a possible top event, search for the direct cause event and indirect cause event which causes the top event layer by layer from top to bottom until the basic cause event, and the logical relations between these events are expressed by using a logic diagram.

\subsection{Case Model Application}

A reservoir in the southwestern structure part is a kind of abnormally high pressure and low permeability lithologic reservoir whose rock formation is tight, so the problem of wellbore integrity is more serious than other areas.

In order to verify the rationality of the structure based on the FTA method, the relevant data such as drilling and completion data, oil production test and production test data and the block productivity construction data is collected. In the process of analysis and description of wellbore risk damage, the damage form of wellbore integrity can be determined as "production casing damage, tubing damage", and combined with the characteristics of single well in this block, this kind of risk is described as "casings of the oil and water wells in this area are badly damaged, the condition of the well is deteriorating, and this leads to the secondary imperfection of well pattern. The problem wells are $60.3 \%$ of the total number of wells in this block according to statistics". So the FTA method is used to evaluate and calculate an example.

In order to clarify the relationship between the risk of wellbore integrity, using risk damage of wellbore as the top event, this time 11 intermediate events and 28 basic events are found out, such as $X i$ $(i=1,2, \ldots, 28)$. Based on the fuzzy logic relation that basic events and intermediate events leads to top events, the fault model of wellbore integrity is established, as illustrated in Figure 1. As long as there is a small number of basic events, top events is likely to occur, and this shows the possibility of existence of wellbore risk is great. 


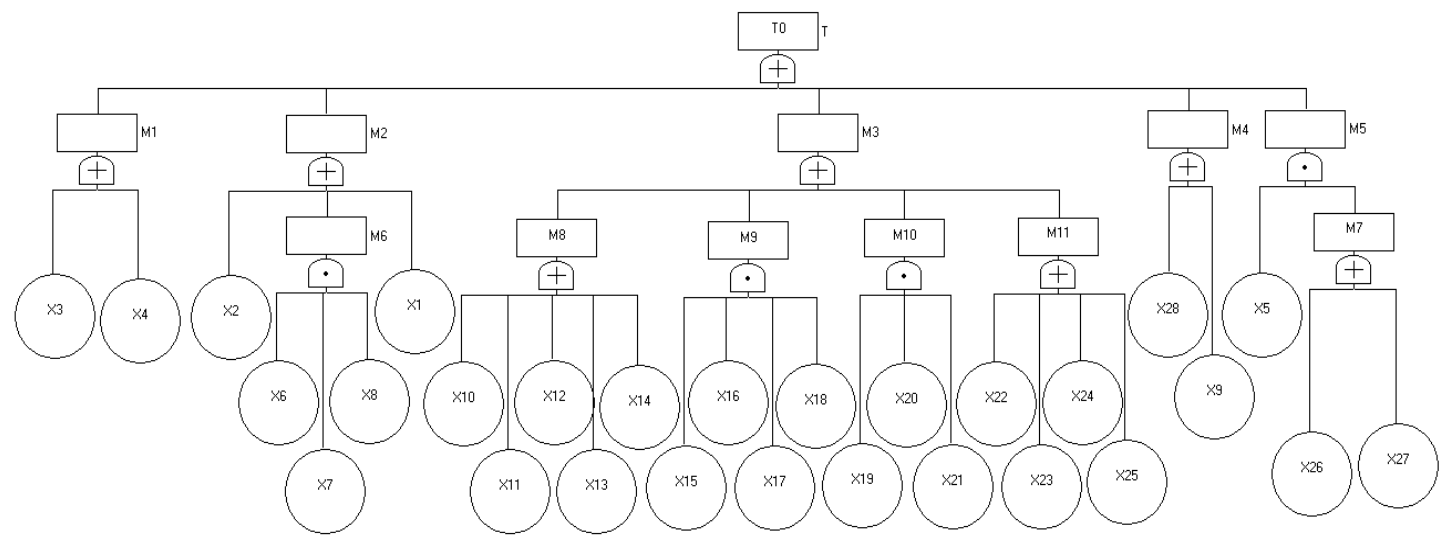

Figure 1. The Establishment of Analysis Model of FTA Logical Tree

Table 1. The Symbol and Meaning of Risk Factors of FTA Analysis System

\begin{tabular}{|c|c|c|c|c|c|c|c|}
\hline Symbol & $\begin{array}{l}\text { Representative } \\
\text { meaning }\end{array}$ & Symbol & $\begin{array}{l}\text { Representative } \\
\text { meaning }\end{array}$ & Symbol & $\begin{array}{l}\text { Representative } \\
\text { meaning }\end{array}$ & Symbol & $\begin{array}{l}\text { Representative } \\
\text { meaning }\end{array}$ \\
\hline T0 & $\begin{array}{l}\text { Risk damage of } \\
\text { wellbore }\end{array}$ & M10 & Tubing damage & X9 & $\begin{array}{l}\text { Annulus bulging } \\
\text { effect }\end{array}$ & X19 & $\begin{array}{l}\text { Too high of lifting } \\
\text { tonnage }\end{array}$ \\
\hline M1 & $\begin{array}{l}\text { Wellhead system } \\
\text { failure }\end{array}$ & M11 & Packer failure & $\mathrm{X} 10$ & $\begin{array}{l}\text { Formation creep } \\
\text { collapse casing }\end{array}$ & $\mathrm{X} 20$ & $\begin{array}{l}\text { Improper pressure } \\
\text { control }\end{array}$ \\
\hline M2 & $\begin{array}{l}\text { Poor cementing } \\
\text { quality }\end{array}$ & $\mathrm{X} 1$ & $\begin{array}{l}\text { Uncentralized } \\
\text { casing }\end{array}$ & X11 & $\begin{array}{l}\text { Casing tieback } \\
\text { damage }\end{array}$ & $\mathrm{X} 21$ & $\begin{array}{l}\text { Hydrogen } \\
\text { embrittlement by } \\
\text { corrosive fluid }\end{array}$ \\
\hline M3 & Pipe string leakage & $\mathrm{X} 2$ & $\begin{array}{l}\text { Not in place of } \\
\text { cement return }\end{array}$ & $\mathrm{X} 12$ & $\begin{array}{l}\text { Casing damage } \\
\text { caused by sand } \\
\text { production }\end{array}$ & $\mathrm{X} 22$ & $\begin{array}{l}\text { Packing element } \\
\text { damage when run in } \\
\text { wellbore }\end{array}$ \\
\hline M4 & $\begin{array}{l}\text { Annulus with } \\
\text { pressure }\end{array}$ & $\mathrm{X} 3$ & $\begin{array}{l}\text { Improper of } \\
\text { wellhead } \\
\text { material }\end{array}$ & $\mathrm{X} 13$ & $\begin{array}{l}\text { Corrosion caused } \\
\text { by oil field water }\end{array}$ & $\mathrm{X} 23$ & $\begin{array}{l}\text { Improper of design } \\
\text { and selection }\end{array}$ \\
\hline M5 & $\begin{array}{l}\text { incompatibility of } \\
\text { pipe string }\end{array}$ & $\mathrm{X} 4$ & $\begin{array}{l}\text { Bad wellhead } \\
\text { seal }\end{array}$ & $\mathrm{X} 14$ & $\begin{array}{l}\text { Hydraulic barrier } \\
\text { of annular } \\
\text { retention fluid }\end{array}$ & $\mathrm{X} 24$ & $\begin{array}{l}\text { Improper operation } \\
\text { and control }\end{array}$ \\
\hline M6 & $\begin{array}{l}\text { Defects of cement } \\
\text { sheath }\end{array}$ & $\mathrm{X} 5$ & $\begin{array}{l}\text { Large difference } \\
\text { of pipe string } \\
\text { design }\end{array}$ & $\mathrm{X} 15$ & $\begin{array}{l}\text { Unreasonable of } \\
\text { strength design }\end{array}$ & $\mathrm{X} 25$ & $\begin{array}{l}\text { Failure of sealing } \\
\text { material }\end{array}$ \\
\hline M7 & $\begin{array}{l}\text { Casing head } \\
\text { movement }\end{array}$ & X6 & $\begin{array}{l}\mathrm{CO}_{2} \text { damage to } \\
\text { the cement } \\
\text { sheath }\end{array}$ & X16 & $\begin{array}{l}\text { Too high of } \\
\text { operating } \\
\text { pressure }\end{array}$ & $\mathrm{X} 26$ & $\begin{array}{l}\text { Reservoir compaction } \\
\text { effect }\end{array}$ \\
\hline
\end{tabular}




\begin{tabular}{|c|c|c|c|c|c|c|c|}
\hline M8 & $\begin{array}{l}\text { Production casing } \\
\text { damage }\end{array}$ & $\mathrm{X} 7$ & Gas channeling & $\mathrm{X} 17$ & $\begin{array}{l}\text { Too high } \\
\text { operating } \\
\text { temperature }\end{array}$ & $\begin{array}{l}\text { of } \\
\times 27\end{array}$ & Surface subsidence \\
\hline M9 & $\begin{array}{l}\text { Damage of down } \\
\text { hole tools }\end{array}$ & X8 & $\begin{array}{l}\text { Low } \\
\text { displacement } \\
\text { efficiency }\end{array}$ & X18 & $\begin{array}{l}\text { Failure } \\
\text { corrosion } \\
\text { resistance }\end{array}$ & of & $\begin{array}{l}\text { Thermal expansion } \\
\text { effect of annulus }\end{array}$ \\
\hline
\end{tabular}

The probability of top events is product of the probability of basic events, so before calculating the risk probability of integrity, every probability of basic events should be first calculated. The probability of basic events should be got by a large number of tests, but can not be achieved in the actual field work, so it is replaced by the frequency approximately.

$$
P t=W t_{t} / \sum_{i=1}^{n} W_{t}
$$

In the formula: $P i$ is the probability of the basic event occurrence, $W i$ is the basic event, $I$ is the number of well.

The analysis system is calculated by using the Boolean algebra simplification method, which Boolean algebra is a kind of structure function and the method of simplifying is using Boolean algebra principle repeatedly, and the simplifying procedure is: 1 . If the algebraic formula includes brackets, they should be removed firstly for functional expansion, 2. Using idempotent law, put similar items together, 3. Making full use of absorption law, simplify directly.

Firstly, analyze the every possible damage risk of wellbore, then determine the probability of each damage risk, lastly the result of probability analysis according to statistics and calculations is made into "probability table of wellbore damage risk", the probability of each event occurrence is shown in Table 2.

Table 2. Calculation Results of Basic Event Probability of Wellbore Damage Risk

\begin{tabular}{lllllllllll}
\hline Basic event & $\mathrm{X}$ & $\mathrm{X}_{2}$ & $\mathrm{X}_{3}$ & $\mathrm{X}_{4}$ & $\mathrm{X}_{5}$ & $\mathrm{X}_{6}$ & $\mathrm{X}_{7}$ & $\mathrm{X}_{8}$ & $\mathrm{X}_{9}$ & $\mathrm{X}_{10}$ \\
\hline probability & 0.52 & 0.02 & 0.01 & 0.05 & 0.002 & 0.5 & 0.6 & 0.8 & 0.041 & 0.3 \\
Basic event & $\mathrm{X}_{11}$ & $\mathrm{X}_{12}$ & $\mathrm{X}_{13}$ & $\mathrm{X}_{14}$ & $\mathrm{X}_{15}$ & $\mathrm{X}_{16}$ & $\mathrm{X}_{17}$ & $\mathrm{X}_{18}$ & $\mathrm{X}_{19}$ & $\mathrm{X}_{20}$ \\
probability & 0.01 & 0.6 & 0.58 & 0.02 & 0.05 & 0.03 & 0.03 & 0.04 & 0.01 & 0.001 \\
Basic event & $\mathrm{X}_{21}$ & $\mathrm{X}_{22}$ & $\mathrm{X}_{23}$ & $\mathrm{X}_{24}$ & $\mathrm{X}_{25}$ & $\mathrm{X}_{26}$ & $\mathrm{X}_{27}$ & $\mathrm{X}_{28}$ & & \\
probability & 0.045 & 0.021 & 0.0016 & 0.0003 & 0.062 & 0.006 & 0.0081 & 0.037 & & \\
\hline
\end{tabular}




\section{Calculation Analysis of System Application}

\subsection{Analysis of Cut Sets and Path Sets}

A set of basic events that cause top events is called the cut set that is generally more than one in system, and in these cut sets, the cut set that do not contain any other cut sets is called the minimum cut set. The minimum cut set plays an important role in FTA method, which is the essential reason of the top event occurrence and indicate the set of occurrence causes of top events. So the more the minimum cut set, the greater the risk of system. The number of minimum cut sets of this system is 40 , as shown in Table 3.

Table 3. The Statistical Table for Calculation of the Minimum Cut Set of System Analysis

\begin{tabular}{cccccccccc}
\hline No. & $\begin{array}{c}\text { minimum } \\
\text { cut sets }\end{array}$ & No. & $\begin{array}{c}\text { minimum cut } \\
\text { sets }\end{array}$ & No. & $\begin{array}{c}\text { minimum } \\
\text { cut sets }\end{array}$ & No. & minimum cut sets & No. & $\begin{array}{c}\text { minimum } \\
\text { cut sets }\end{array}$ \\
\hline 1 & X3 & 9 & X15X16X17X18 & 17 & X12 & 25 & X26X5 & 33 & X23 \\
2 & X6X7X8 & 10 & X19X20X21 & 18 & X13 & 26 & X4 & 34 & X24 \\
3 & X10 & 11 & X22 & 19 & X14 & 27 & X2 & 35 & X25 \\
4 & X28 & 12 & X9 & 20 & X27X5 & 28 & X1 & 36 & X11 \\
5 & X26X5 & 13 & X23 & 21 & X3 & 29 & X15X16X17X18 & 37 & X12 \\
6 & X4 & 14 & X24 & 22 & X6X7X8 & 30 & X19X20X21 & 38 & X13 \\
7 & X2 & 15 & X25 & 23 & X10 & 31 & X22 & 39 & X14 \\
8 & X1 & 16 & X11 & 24 & X28 & 32 & X9 & 40 & X27X5 \\
\hline
\end{tabular}

In the FTA method, a set of basic events that can not cause top events is called the path set. A set of minimal basic events that can not cause top events is called the minimal path set. Firstly, transform it to a dual system, then get the minimum cut sets of new system that is the minimum path set of original system.

The number of minimum path sets of this system is 72 , represented as $\mathrm{K} 72$.

$$
\begin{aligned}
& K 1=\left\{X_{\mathrm{g}}^{*} X_{6}^{*} X_{10}^{*} X_{2 \mathrm{~g}}^{*} X_{26}^{*} X_{4}^{*} X_{2}^{*} X_{1}^{*} X_{1 \mathrm{~g}}^{*} X_{1 \mathrm{~g}}^{*} X_{22}^{*} X_{\mathrm{g}}^{*} X_{2 \mathrm{~g}}^{*} X_{24}^{*} X_{2 \mathrm{~g}}^{*} X_{11}^{*} X_{12}^{*} X_{1 \mathrm{~g}}^{*} X_{1 \mathrm{~s}}^{*} X_{2 \%}^{*}\right\}, \ldots \\
& K 3=\left\{X_{2}^{*} X_{6}^{*} X_{10}^{*} X_{2 g}^{*} X_{26}^{*} X_{4}^{*} X_{2}^{*} X_{1}^{*} X_{16}^{*} X_{19}^{*} X_{22}^{*} X_{9}^{*} X_{11}^{*} X_{12}^{*} X_{19}^{*} X_{14}^{*} X_{27}^{*} X_{28}^{*} X_{24}^{*} X_{26}^{*}\right\}, \ldots \\
& K 50=\left\{X_{2}^{*} X_{7}^{*} X_{10}^{*} X_{2 \mathrm{~g}}^{*} X_{\mathrm{g}}^{*} X_{4}^{*} X_{2}^{*} X_{1}^{*} X_{18}^{*} X_{20}^{*} X_{22}^{*} X_{9}^{*} X_{11}^{*} X_{12}^{*} X_{19}^{*} X_{14}^{*} X_{2 \mathrm{~g}}^{*} X_{24}^{*} X_{26}^{*}\right\}, \ldots \\
& K 52=\left\{X_{\mathrm{g}}^{*} X_{\mathrm{g}}^{*} X_{10}^{*} X_{2 \mathrm{~g}}^{*} X_{\mathrm{g}}^{*} X_{4}^{*} X_{2}^{*} X_{1}^{*} X_{1 \mathrm{~g}}^{*} X_{21}^{*} X_{22}^{*} X_{\mathrm{g}}^{*} X_{11}^{*} X_{12}^{*} X_{1 \mathrm{~g}}^{*} X_{14}^{*} X_{2 \mathrm{~s}}^{*} X_{24}^{*} X_{2 \mathrm{~s}}^{*}\right\}, \ldots \\
& K 72=\left\{X_{\mathrm{g}}^{*} X_{\mathrm{g}}^{*} X_{10}^{*} X_{2 \mathrm{~g}}^{*} X_{26}^{*} X_{4}^{*} X_{2}^{*} X_{1}^{*} X_{1 \mathrm{~B}}^{*} X_{19}^{*} X_{22}^{*} X_{\mathrm{g}}^{*} X_{2 \mathrm{~g}}^{*} X_{24}^{*} X_{2 \mathrm{~g}}^{*} X_{11}^{*} X_{12}^{*} X_{1 \mathrm{~g}}^{*} X_{1 \mathrm{~A}}^{*} X_{28}^{*}\right\} \text {. }
\end{aligned}
$$

\subsection{Fuzzy Logic Relation Analysis}

In the analysis of wellbore integrity, every basic event and intermediate event respectively meet the fuzzy or gate logic relation. Namely, suppose last event is $A$ and next event is $B_{1}, B_{2}, \ldots B_{n}$, if any of $B$ occurs, A may occur, then $A$ and $B_{1}, B_{2}, \ldots, B_{n}$ satisfies the fuzzy domain gate logic relation.

$$
\mathrm{A}=\mathrm{B}_{1}(\mathrm{u}) \mathrm{UB}_{2}(\mathrm{u}) \mathrm{U} \ldots . \mathrm{UB}_{\mathrm{n}}(\mathrm{u})
$$




\subsection{Importance Analysis and Calculation}

The important degree of each basic event is analyzed and calculated from the logical structure of FTA analysis method, and the calculation formula is as follows:

$$
I \oplus(t)=\frac{1}{2^{n-2}} \Sigma[\varphi(1, x t)-\sigma(0, x t)]
$$

In the formula, $I_{\phi}(i)$ is the structure importance of the basic event, $\phi(1, x i)$ is the state of the top event when the state of the basic event status is $1, \phi(0, x i)$ is the state of the top event when the state of the basic event status is $0, \mathrm{n}$ is the number of basic events.

Using the nature that the probability function of top events is a multiple linear function, the probability importance of basic events that is influence degree of the occurrence probability of basic events on the occurrence probability of top events, can be obtained by solving first partial derivative of variables, and the calculation formula is as follows:

$$
I_{8}(t)=\frac{\partial Q}{\partial_{5 !}}
$$

In the formula, $I_{Q}(i)$ is the probability importance of the basic event, $Q$ is the probability of top events, $q_{i}$ is the probability of the basic event.

\begin{tabular}{|c|c|c|c|c|c|c|c|}
\hline $\begin{array}{l}\text { Basic } \\
\text { event }\end{array}$ & $\begin{array}{l}\text { Uncentralized } \\
\text { casing (X1) }\end{array}$ & $\begin{array}{l}\text { Not in place of } \\
\text { cement return } \\
\text { (X2) }\end{array}$ & $\begin{array}{l}\text { Formation creep } \\
\text { collapse casing } \\
\text { (X10) }\end{array}$ & $\begin{array}{l}\text { Casing damage } \\
\text { caused by sand } \\
\text { production (X12) }\end{array}$ & $\begin{array}{l}\text { Corrosion caused } \\
\text { by oil field water } \\
\text { (X13) }\end{array}$ & $\begin{array}{l}\text { Failure of } \\
\text { sealing } \\
\text { material (X25) }\end{array}$ & $\begin{array}{l}\text { Annulus } \\
\text { bulging effect } \\
\text { (X9) }\end{array}$ \\
\hline $\begin{array}{l}\text { structure } \\
\text { importance }\end{array}$ & 0.05 & 0.05 & 0.05 & 0.05 & 0.05 & 0.05 & 0.05 \\
\hline $\begin{array}{l}\text { probability } \\
\text { importance }\end{array}$ & 0.9 & 0.9 & 0.9 & 0.9 & 0.9 & 0.9 & 0.9 \\
\hline $\begin{array}{l}\text { risk } \\
\text { importance } \\
\text { coefficient }\end{array}$ & 0.3043 & 0.034 & 0.1014 & 0.2029 & 0.2705 & 0.0209 & 0.0139 \\
\hline $\begin{array}{l}\text { Basic } \\
\text { event }\end{array}$ & $\begin{array}{l}\text { Bad wellhead } \\
\text { seal (X4) }\end{array}$ & $\begin{array}{l}\text { Thermal } \\
\text { expansion effect } \\
\text { of annulus (X28) }\end{array}$ & $\begin{array}{l}\text { Packing element } \\
\text { damage when } \\
\text { run in wellbore } \\
\text { (X22) }\end{array}$ & $\begin{array}{l}\text { Hydraulic barrier } \\
\text { of annular retention } \\
\text { fluid (X14) }\end{array}$ & $\begin{array}{l}\mathrm{CO}_{2} \text { damage to } \\
\text { the cement } \\
\text { sheath }(\mathrm{X} 6)\end{array}$ & $\begin{array}{l}\text { Gas } \\
\text { channeling } \\
\text { (X7) }\end{array}$ & $\begin{array}{l}\text { Low } \\
\text { displacement } \\
\text { efficiency (X8) }\end{array}$ \\
\hline structure & 0.05 & 0.05 & 0.05 & 0.05 & 0.0167 & 0.0167 & 0.0167 \\
\hline
\end{tabular}

Table 4. Calculation Results of the Parameters Importance of the Wellbore Damage Risk 


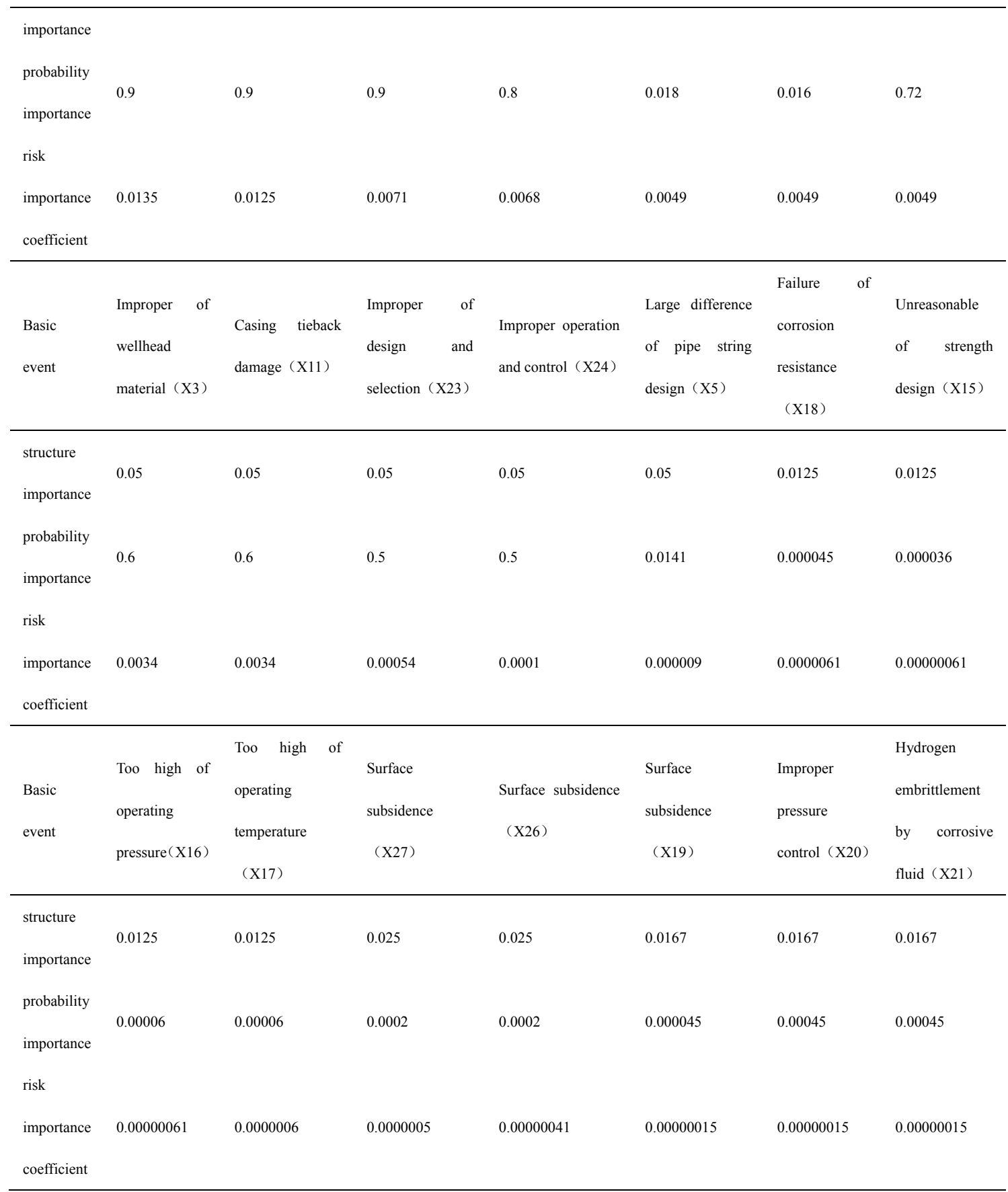

Table 5. Classification of Calculation Results of Basic Events Importance

\begin{tabular}{lll}
\hline Classification & Risk rank & Description \\
\hline & & Three importance parameter values is high, indicating that this kind of \\
& basic events has great influence on damage risk of wellbore from both \\
IV & the logical structure and the occurrence probability, and this kind of \\
& events should be considered first when the measure of preventing \\
& wellbore integrity is drafted.
\end{tabular}


The probability importance and structure importance is large, and this

III Importance

\section{kind} the measure of preventing wellbore integrity is drafted.

The probability importance is large and the structure importance is the

II Middle

Low second, this shows that the occurrence probability of this kind of events has a significant impact on top events.

Three importance degree are small, this shows the risk effect on top events with changing probability of this kind of events is not obvious, generally as a reference factor.

The order of structure importance of this system is as follows:

$$
\begin{aligned}
& \mathrm{I}(3)=\mathrm{I}(10)=\mathrm{I}(28)=\mathrm{I}(5)=\mathrm{I}(4)=\mathrm{I}(2)=\mathrm{I}(1)=\mathrm{I}(22)=\mathrm{I}(9)=\mathrm{I}(23)=\mathrm{I}(24)=\mathrm{I}(25)=\mathrm{I}(11)=\mathrm{I}(12)=\mathrm{I}(13)=\mathrm{I}(14)>\mathrm{I}(26)=\mathrm{I}( \\
& 27)>\mathrm{I}(20)=\mathrm{I}(21)=\mathrm{I}(7)=\mathrm{I}(8)=\mathrm{I}(6)=\mathrm{I}(19)>\mathrm{I}(16)=\mathrm{I}(17)=\mathrm{I}(18)=\mathrm{I}(15)
\end{aligned}
$$

Risk importance coefficient: measure importance standard of the basic event from both perspective of sensitivity and probability, and the calculation formula is I.

$$
c_{t}=\frac{\theta \ln Q}{\theta \ln q_{t}}
$$

In the formula, $C_{i}$ is the risk importance coefficient of the basic event, $Q$ is the probability of top

events, $q_{i}$ is the probability of the basic event.

Using the nature that the probability function of top events is a multiple linear function, the probability importance of basic events can be obtained by solving first partial derivative of $q i$ variables, then calculation results of the importance coefficient of each event are got, as shown in Table 4.

According to the results, the order of risk importance coefficient of each basic event is as follows:

$$
\begin{aligned}
& \mathrm{Cg}(1)>\mathrm{Cg}(13)>\mathrm{Cg}(12)>\mathrm{Cg}(10)>\mathrm{Cg}(2)=\mathrm{Cg}(2)>\mathrm{Cg}(25)>\mathrm{Cg}(9)>\mathrm{Cg}(4)>\mathrm{Cg}(28)>\mathrm{Cg}(22)>\mathrm{Cg}(14)>\mathrm{Cg}(8)= \\
& \mathrm{Cg}(6)=\mathrm{Cg}(7)>\mathrm{Cg}(11)=\mathrm{Cg}(3)=\mathrm{Cg}(3)>\mathrm{Cg}(23)>\mathrm{Cg}(24)>\mathrm{Cg}(5)>\mathrm{Cg}(15)=\mathrm{Cg}(16)=\mathrm{Cg}(17)>\mathrm{Cg}(18)>\mathrm{Cg}(27) \\
& >\mathrm{Cg}(26)>\mathrm{Cg}(21)=\mathrm{Cg}(20)>\mathrm{Cg}(19)>\mathrm{Cg}(7)=\mathrm{Cg}(8)=\mathrm{Cg}(6)
\end{aligned}
$$

Compared with the well number ratio $100 \%$ which exist actual damage, the probability calculation result of top event is 0.9961 , and the error is only 0.0039 and the relative error is within the allowable range of project. This shows the FTA evaluation model is reasonable, and the risk analysis method of wellbore based on FTA is feasible, so the occurrence probability of high risk importance coefficient of basic events should be strictly controlled in the process of well completion, thereby the risk of oil and gas out of control caused by wellbore damage is reduced.

Through actual analysis, $41 \%$ of the total casing damage wells are water injection wells, water injection is the main cause of casing damage. Because of poor water quality or heavy polluted reservoir or high water injection pressure, the casing of water injection well has problems such as casing damage and 
hole shrinkage. Low permeability of formation and development of water sensitive clay layer lead to poor conductivity; unreasonable cement return height or too high injection pressure lead to casing deformation or breakage of water injection wells; the oil well casing damage is near reservoir area, and the frequent fracturing of oil wells, the great buried depth of the reservoir and high ground stress can also cause damage to the casing.

\section{Conclusions and Suggestions}

By comparing the order of probability importance and risk important coefficient of each event, the most main factors that influence the damage risk of this block include uncentralized casing, corrosion caused by oil field water, casing damage caused by sand production, casing collapse caused by formation creep, unreasonable cement return height and seal material failure.

According to the FTA analysis method, the risk factors should be strengthened to control and events of high probability should be focused on prevention and control in the completion process, specific corresponding measures: centralize the casing as far as possible, improve the uniformity of the thickness of cement sheath, improve the performance of the cement slurry system, require smooth of the well trajectory, improve the collapsing strength of casing, well completion with thick wall casing of high strength in oil layer section, increase thickness and steel grade of casing, improve cementing quality, increase cement return height. In addition, attention should be paid to the water injection well to improve the water quality and enhance strength and corrosion resistance of casing, and at the same time, the cement is required to return to the ground.

Because of the different reservoir conditions leading to the change of block conditions and major technology and down hole tools, the analysis conclusion is not immutable. Wellbore integrity failure is the combined action of a variety of basic events, therefore "one well corresponded with one strategy" need to be worked out according to the system analysis, the probability calculation of risk factor of "last events" or "intermediate events" should be analyzed targeted, and the main factors of wellbore risk damage should be clearly studied, these can give better suggestion for control measures of wellbore integrity of similar wells or blocks.

\section{Acknowledgement}

The author would like to thank Feng Zhang and Yubao Li for permission to publish this paper. Operationally sensitive data has been altered from the original values.

\section{References}

Dethlefs, J. C., \& Chastain, B. (n.d.). Assessing well integrity risk: A qualitative model. SPE 142854.

Hou, F. J., Xiao, G. P., \& Yang, S. P. (2001). Study on fuzzy fault tree analysis and its application Journal of Hebei Normal University (Natural Science Edition), 25(4), 464-468.

Jiang, W. D., Li, X. B., \& Li, Q. Y. (2011). Analysis of the fault tree on the basis of fuzzy logic relation. 
Shanxi Coal, 2011(3)

Pattillo, P. D., Payne, M. L., Webb, T. R., \& Tobago, \& Sharadin, J. H. (n.d.). Application of decision analysis to a deep water well integrity assessment.

Shi, S. L., \& Lu, B. T. (2004). Development and application of fault tree analysis system based on visualization. Engineering Science, 6(11), 66-71.

State administration of production safety supervision and management. (2015). Safety evaluation. Coal industry publishing house, Beijing.

WU Guohua. (n.d.). The accident tree mapping and analysis system based on NET. CHINA SCIENCE AND TECHNOLOGY INFORMATION (pp. 118-119).

Zhang, J., Dai, Q., \& Zhang, Y. (2015). Identification and control of wellbore safety risks during the well testing of HPHT sulfur gas wells. NATUR. GAS IND, 35(1), 120-125. 